リウム濃度が相当に濃く，したがって生成ビタミン $\mathrm{B}_{1}$ 量が多く，実際の定量にはでく少量の試料しか用いなか

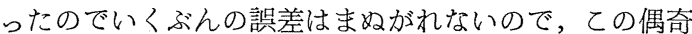
交互性についてはその傾向をわずかに推察するにすぎな いが，脂肪酸ナトリウムの結晶構造 ${ }^{13)}$, 脂肪酸ナトリウ ム誘導体（フレーバー）の検知性 ${ }^{14}$ などにおける偶奇性 からみて，必ずしも根拠の無いものとはいえず，今後さ らに詳細な検討を試みたい。

今回の試験で対象とした卵アルブミンは，中性タンパ クであり，人間の皮膚，つわ，毛などのケラチン類とは 種々の点で異なり，一つのモデル実験に過ぎないが，前 述のような利点があり，限られた範囲での刺激判定には 有効である。

終わりにTDS の提供を受けた大阪田辺研の内海勇氏，東京 農大生物化学研究室, ならびに 実験に当たり 終始御指導, 御援 助を賜った東京農大佐橋佳一教授, 当社藤本昭工場長, 中山昭 彦研究所長, 野口駿氏, 関口英雄氏らに厚く感謝する。

（昭和 39 年 12 月 21 日受理）
文

献

1) K. Neumann, J.G. Aalbers, Fette-Seifen Anstrichmittel, 62 [11], 1053 (1960)

2) F.W. Putnum, Advances in Protein Chem., 4, 76 (1948)

3）青木, 油脂, 11 (1963) 2 (1964)

4) M.L. Anson, J. Gen. Physiol., 23, 239 (1939)

5) M.L. Anson, J. Gen. Physiol., 24, 399 (1941)

6) A.E. Mirsky, J. Gen. Physiol., 24, 709 (1941)

7) E.J. Scott, J.B. Lyon, J. of Investigative Dermatology, 21, 199 (1953)

8) 武居, 木村, 生化学, 32, 525 (1960)

9）関口, 木村, 吉野, 未発表

10) W. Blaich, Fette-Seifen Austrichmittel, 63 [7], 622 (1961)

11）佐橋, 柴崎, 農化, 25, 57 (1951)

12）内海, 原田, 河野, 第 143 回ビタミン研究会および日本 薬学会総会 (1964 年 4 月) 発表

13）野口, 仁科, 農化, 38, 207 (1964)

14) P.W. Meijboom, J. Am. Oil Chemists' Soc., 41, $326(1964)$

粉末洗剤中の炭酸ナトリウムと炭酸水素

$$
\begin{aligned}
& \text { ナトリウムとの定 量 } \\
& \text { 岩 本 行 信・新 井 政 義・小黒悌次郎 } \\
& \text { ミッワ石輸株式会社東京工場 (東京都畦田寺島町) }
\end{aligned}
$$

\title{
Determinaton of Sodium Carbonate and Sodium Hydrogencarbonate in Detergent Powders
}

\author{
Yukinobu Iwamoto, Masayoshi Arai and Teijirō Oguro \\ Tokyo Factory, Mitsuwa Soap Co Ltd. (Terashima-chö, Tokyo)
}

In order to determine $\mathrm{Na}_{2} \mathrm{CO}_{3}$ and $\mathrm{NaHCO}_{3}$ in the detergent powder, hydrochloric acid was added to the two detergent samples, one of which was previously heated at $160^{\circ} \mathrm{C}$, and the others was not heated. $\mathrm{CO}_{2}$ liberated was absorbed in the N/10-KOH solution, and $\mathrm{K}_{2} \mathrm{CO}_{3}$ formed was determined by titration with $N / 2-\mathrm{HCl}$ solution. The contents of $\mathrm{Na}_{2} \mathrm{CO}_{3}$ and $\mathrm{NaHCO}_{3}$ in the detergent sample were calculated from the difference of titration values and almost satisfactory results were obtained.

\section{1 緒言}

セッケン，洗剤中の炭酸塩，炭酸水素塩の定量に関し ては，R.M. Kelley らの報告 ${ }^{1)}$ があり，かれらは試料を $200^{\circ} \mathrm{C}$ に $30 \mathrm{~min}$ 加熱し，炭酸水素塩の分解による発生 炭酸ガスを炭酸ガス吸収管に吸収させ，その重量増加を 測定し, さらに残留炭酸塩に塩酸を加えて, 生ずる炭酸 ガスを A.O.C.S.Da 19a-42 に準じて Ascarite 吸収 
管に吸収させ，その重量増加を測定し，てれらの測定值 から炭酸塩および炭酸水素塩を定量した。同報告で，炭 酸水素ナトリウムは $200^{\circ} \mathrm{C}$ に $30 \mathrm{~min}$ 加熱すれば, 約 98\% が炭酸ガスを放って変化すると述べている。

洗剤中の炭酸塩定量のために, N.M. Schuck ら ${ }^{2)}$ は A.O.C.S.Da 19 b-42 のセッケン中の 炭酸塩の定量法を 洗剤に適用するてとを報告しているが JIS K 3362-1955 合成洗片試験方法にも炭酸根 (概量) の定量法が述べて ある。また洗剤の場合ではないが，JIS G 1211-1963 鉄 および鋼の炭素分析方法の中に，炭酸ガスを諸種の方法 で定量するてとが述べてある。

著者らは R.M. Kelley らの方法 ${ }^{11}$ より，粉末洗鼡中 の炭酸ナトリウムおよび炭酸水素ナトリウムを定量しよ うと試み，ただ Ascarite の代わりにN/10一水酸化カリ ウム水溶液に発生炭酸ガスを吸収させ，乙れを $N / 2$-塩 酸水溶液で滴定してみた。その結果, 炭酸水素ナトリウ ムは $120 \sim 150^{\circ} \mathrm{C}$ において分解がはなはだしく, 炭酸が スが急速に発生して $N / 10$-水酸化カリウム水溶液に吸収 きれない場合があった。そてで試料をあらかじめし $160^{\circ} \mathrm{C}$ に加熱して炭酸水素ナトリウムを分解したもの と, 加熱しないものとの 2 個に対し, 塩酸を加えて発生 する炭酸ガスを $N / 10$-水酸化カリウム水溶液に吸収さ せ，てれを滴定してほぼ満足できる結果を得た。

\section{2 実験}

\section{$2 \cdot 1$ 定量法の原理}

試料を 2 個七ョウ取し, 1 個は $160^{\circ} \mathrm{C}$ 亿加熱して含有 する炭酸水素ナトリウムを完全に炭酸ナトリウムに変光 る。他の 1 個はそのままとし,それぞれ別に密閉容器中に 入れて $10 \%$ 塩酸を滴下し, 発生する炭酸ガスを $N / 10$-水 酸化カリウム水溶液に吸収させ, 生成する炭酸カリウム を $N / 2$-塩酸で滴定し， $\mathrm{pH} 8.4 \sim 4.0$ の間の各滴定值か ら試料中の炭酸ナトリウムと炭酸水素ナトリウムとの含 有率を求める。反応式は式 (1), (2), (3), (4), (5), (6) のとおりである。

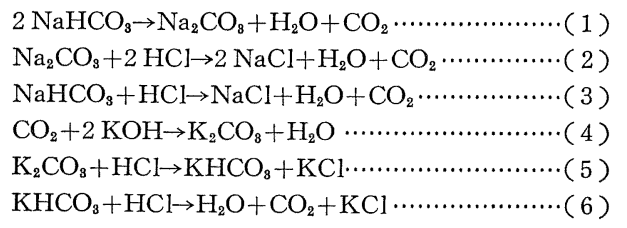

\section{$2 \cdot 2$ 試薬, 試料, 器具}

$2 \cdot 2 \cdot 1$ 試薬 $1 N$-水酸化力リウム水溶液, $30 \%$ 水 酸化カリウム水溶液, $10 \%$ 塩酸水溶液, N/2-塩酸標準 液

$2 \cdot 2 \cdot 2$ 試料炭酸ナトリウムおよび 炭酸水素ナト リウム（共に試薬特級, 結晶水なし), 市販粉末洗剂 2 種 $(\mathrm{A} お$ よび $\mathrm{B})$

$2 \cdot 2 \cdot 3$ 器具平底フラスコ(口がすり合わせで首の
長いもの, 内容 $100 \mathrm{~m} l$ ), ガス吸収管 (内容 $200 \mathrm{ml}$ ), 真空蒸留受器ウィッドマー (以下 $\mathrm{W}$ 型受器之略称), 以 上を Fig.-1 のように組み立てる。そのほか $\mathrm{pH} メ ー$ ター, マグネチックスタラーなどを使用。

\section{$2 \cdot 3$ 方 法}

$2 \cdot 3 \cdot 1$ 試料を 2 個,適当量ずつ平底フラスコにヒョウ 取する, $N / 2$-塩酸滴定量が大体 $10 \mathrm{~m} l$ くらいになるよう に試料七ョウ取量を加減する。炭酸ナトリウムのみなら ば約 $0.6 \mathrm{~g}$ )。その 1 個を電気定温乾燥器に入れて $160^{\circ} \mathrm{C}$ に約 $3 \mathrm{hr}$ 加熱する。こてで含有する炭酸水素ナトリウ ムは式 (1) のように分解する。炭酸水素ナトリウム単独 についての予備試験では, この条件下の分解率は $99.3 \%$ 以上であった（重量減により測定）。

2.3・2 Fig.-1 の吸収管Aには $30 \%$ 水酸化カリウム を入れて, 空気中の炭酸ガスの影響を除く。試料 $(2 \cdot 3 \cdot 1$ で加熱分解したもの，または加熱しないもの）の入って いる平底フラスコは $\mathrm{W}$ 型受器 $\mathrm{C}$ と連結し、コック $\mathrm{D}$ を

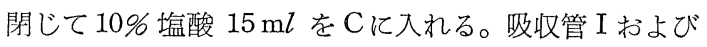
Jにはそれぞれ $1 N$-水酸化カリウム $20 \mathrm{~m} l$ ずつをピペ ットで注入し，標線まで蒸留水を加えて $200 \mathrm{~m} l$ とし, 真空用ゴム管を用いて Fig.-1 のようにセットする。

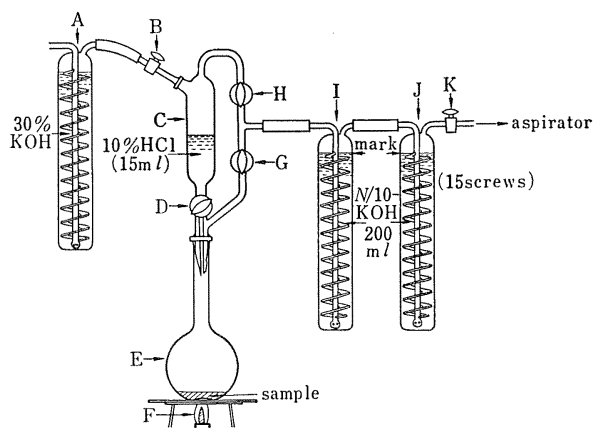

Fig.-1 Apparatus.

$2 \cdot 3 \cdot 3$ つぎに $10 \%$ 塩酸を徐々に滴下する。発生す る炭酸ガスは，その約 $98 \%$ が吸収管 I で吸収される。 さらにJでほぼ完全に (99\% 以上) 吸収される。滴下が 終わったら，バーナーの小さな焱で徐々に試料の入って いるフラスコを加熱する。しばらく気ホウの発生が続い た後, 液中に溶存する炭酸ガスが完全に放出されると, もはや吸収管中の気ホウの上昇が認められなくなる（約 10 12 min 後)。乙こでコックKを閉じ直ちにアスピレ 一ターに接続し, 再びコックKを徐々に開き, バーナー の火を消し，コックBを開いて炭酸がスを除いた空気を 通し (5 min), 装置中に残っている炭酸ガスを水酸化 カリウム水溶液に吸収させる。

2・3・4 コックKを閉じ,アワの上昇がやんでから，吸 収管 I, J の内容液をビーカーに移し, 蒸留水一定量で 吸収管を十分洗ってその洗液を合わせ，直ちにN/2-塩 


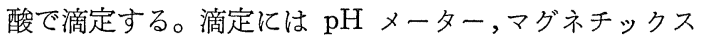
タラーを用い, $\mathrm{pH} 8.4 \sim 4.0$ の間の $N / 2$-塩酸消費量を 求める。

上記とまったく同様に, $1 \mathrm{~N}$-水酸化カリウム $20 \mathrm{~m} l$ ず つを吸収管にとり, 蒸留水を加えて $200 \mathrm{~m} l$ とし, 炭酸 ガスを除いた空気を $5 \mathrm{~min}$ 通しててれを滴定し（pH $8.4 \sim 4.0$ 間) 空試験とする。

\section{4 算 出 式}

$N / 2$-塩酸消費量 ( $\mathrm{pH}$ 8.4 4.0 間) は炭酸カリウムの 生成量の半量に対応する。最初に試料を加熱しなかっ た場合の $N / 2$ 塩酸消費量を $A \mathrm{ml}$ ，あらかじめ試料を $160^{\circ} \mathrm{C}$ に加熱した場合の $N / 2$-塩酸消費量を $B \mathrm{ml}$ とす る。ただし $A \mathrm{~m} l, B \mathrm{~m} l$ は空試験の $N / 2$-塩酸消費量を 差し引いた量を, さらに 2 個の試料のどちらかの採取量 に対するように換算した值である。

以上のように考觉ると， $2(A-B) \mathrm{m} l$ は陚料中の炭酸 水素ナトリウムの全量を直接 $N / 2$-塩酸で中和する $(\mathrm{pH}$ 4.0 まで) 量に等しい。したがって試料中の炭酸水素ナ トリウム含有率はつぎのとおり算出される。

$$
\mathrm{NaHCO}_{3}(\%)=\frac{8.40 \times(A-B) \times f}{\text { 試料七 } \equiv \text { ウ取量 }(\mathrm{g})}
$$

ただし $f$ は $N / 2$-塩酸の力価である。

また $2(2 B-A) \mathrm{m} l$ は陚料中の炭酸ナトリウムを直 接 $N / 2$-塩酸で中和する ( $\mathrm{pH} 4.0$ まで) 量に等しい。し たがって武料中の炭酸ナトリウム含有率はつぎのとおり 算出される。

$$
\begin{array}{r}
\mathrm{Na}_{2} \mathrm{CO}_{8}(\%)=\frac{5.30(2 B-A) \times f}{} \\
3 \text { 試料七 結 果取量 }(\mathrm{g}) \\
\text { 考察 }
\end{array}
$$

\section{3 結果亡考察}

\section{1 炭酸ナトリウムおよび 炭酸水素ナトリウムの場 合}

炭酸ナトリウム，炭酸水素ナトリウムのおのおのおよ び両者の混合物について実験し，ての定量法は正確さ， 再現性とも大体満足できることを確認した。しかし，炭 酸ガスの発生，吸收時のガス漏れや，滴定時の空気中の 炭酸ガスのためか, 多少結果にバラッキを生じた。結果 は Table-1 のとおりである。ただし，試料 $\mathrm{Na}_{2} \mathrm{CO}_{3}$,
Table-1 $\mathrm{Na}_{2} \mathrm{CO}_{3}$ and $\mathrm{NaHCO}_{3}$.

\begin{tabular}{l|c|c|c}
\hline \multicolumn{2}{c|}{ Weight of sample $*$} & \multicolumn{2}{|c}{ Found (Recovery) } \\
\hline $\mathrm{Na}_{2} \mathrm{CO}_{8}(\mathrm{~g})$ & $\mathrm{NaHCO}_{3}(\mathrm{~g})$ & $\mathrm{Na}_{2} \mathrm{CO}_{3}(\%)$ & $\mathrm{NaHCO}_{3}(\%)$ \\
\hline 0 & 0.8421 & -0.7 & 101.2 \\
0 & 1.0475 & 0 & 99.4 \\
0 & 0.8216 & 4.3 & 98.4 \\
0.5732 & 0 & 97.1 & 3.7 \\
0.3419 & 0.3321 & 101.2 & 101.2 \\
0.4921 & 0.2998 & 98.3 & 101.5 \\
\hline
\end{tabular}

* Weight of sample $\left(\mathrm{Na}_{2} \mathrm{CO}_{8}\right.$ or $\left.\mathrm{NaHCO}_{8}\right)$ is calculated as pure matter (purity 100\%). Weight of sample $\left(\mathrm{Na}_{2} \mathrm{CO}_{3}\right.$ or $\left.\mathrm{NaHCO}_{8}\right)$, which is not heated $160^{\circ} \mathrm{C}$ is about half of weight shown in table.

$\mathrm{NaHCO}_{3}$ はあらかじめ JIS K 8625, 8622 の試験法に より N/2-塩酸で滴定し, 純度がほぼ 100\% であるとと を確認し,さらに厳密に 100\% であったときの試料七ョ ウ取量化換算してある。

\section{$3 \cdot 2$ 市販粉末洗剂の場合}

市販粉末洗剤 2 種 (AおよびB) につき，炭酸ナトリ ウムおよび炭酸水素ナトリウムの定量を行ない，さらに ての両洗剤に炭酸ナトリウム，炭酸水素ナトリウムを添 加したものについても定量を行ない，大体満足できる結 果を得た。結果を Table-2 亿示す。

この定量法は発生する炭酸ガスのみを定量するので, 洗剤中に過ホウ酸塩のような酸素を発生するビルダーが 共存しても，定量結果に影響はない子推測するが，炭酸 ナトリウムと炭酸水素ナトリウム以外の物質で，ての定 量操作中に炭酸がスを発生する物質が存在すると，結果 に影響を与える。また試料を $160^{\circ} \mathrm{C}$ 亿加熱する際，炭 酸ナトリウムからも炭酸ガスを発生させる物質（酸また はエステルなどが該当すると思われる）が共存すると結 果涼響を与えると推測する。

（昭和 39 年 12 月 11 日受理）

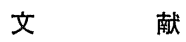

1) R.M. Kelley, E.W. Blank, J. Am. Oil Chemists' Soc., 26, 685 (1949)

2) N.M. Schuck, W.H. Koester, J. Am. Oil Chemsts' Soc., 27, 321 (1950)

\begin{tabular}{|c|c|c|c|c|c|c|c|c|}
\hline \multirow{2}{*}{$\begin{array}{l}\text { Deter- } \\
\text { gent }\end{array}$} & \multicolumn{2}{|c|}{$\begin{array}{l}\text { Content in detergent } \\
(\mathrm{X})\end{array}$} & \multicolumn{2}{|c|}{ Added } & \multicolumn{2}{|c|}{ Found (Total) (Y) } & \multicolumn{2}{|c|}{ Recovered $(Y-X)$} \\
\hline & $\mathrm{Na}_{2} \mathrm{CO}_{3}(\%)$ & $\mathrm{NaHCO}_{3}(\%)$ & $\mathrm{Na}_{2} \mathrm{CO}_{3}(\%)$ & $\mathrm{NaHCO}_{3}(\%)$ & $\mathrm{Na}_{2} \mathrm{CO}_{3}(\%)$ & $\mathrm{NaHCO}_{3}(\%)$ & $\mathrm{Na}_{2} \mathrm{CO}_{3}(\%)$ & $\mathrm{NaHCO}_{3}(\%)$ \\
\hline A & unknown & unknown & 0 & 0 & $\left.\begin{array}{l}16.1 \\
13.5\end{array}\right\} \begin{array}{r}\text { mean } \\
14.8\end{array}$ & $\left.\begin{array}{l}20.8 \\
22.8\end{array}\right\} \begin{array}{r}\text { mean } \\
21.8\end{array}$ & - & - \\
\hline A & 14.8 & 21.8 & 0 & 20.0 & 15.9 & 40.9 & 1.1 & 19.1 \\
\hline A & 14.8 & 21.8 & 0 & 20.0 & 16.5 & 40.3 & 1.7 & 18.5 \\
\hline B & unknown & unknown & 0 & 0 & 0.5 & 0.8 & - & - \\
\hline B & 0.5 & 0.8 & 9.9 & 10.0 & 9.6 & 11.1 & 9.1 & 10.3 \\
\hline B & 0.5 & 0.8 & 9.9 & 10.0 & 9.3 & 11.6 & 8.8 & 10.8 \\
\hline
\end{tabular}

Table-2 Commercial detergent powders. 